\title{
How emerging market investors' value competitors' customer equity: Brand crisis spillover in China
}

Peng Zou

Guofeng Li

Submission: August 2014

Revision: September 2015

Acceptance: December, 2015

Acknowledgment: This research was partially funded by a research grant from the National Science Foundation of China under project No. 71272174 and the Science Foundation of Heilongjiang Province under project No. G201304. Send correspondence to Pen Zou (corresponding author), School of management, Harbin Institute of Technology, 13 Fayuan St. Harbin China 150001, Email: zoupeng@ hit.edu.cn, Tel:+8645186414042. 


\begin{abstract}
Brand crisis not only damages customer equity of the affected brand, but also spill over to non-affected competitors when perceived as guilty by association. Therefore, understanding about the indirect financial costs of brand crisis spillover is critical, because customer equity puts much emphasis on the bottom-line financial value. However, little is understood about financial costs to competitors associated with the spillover effect. This study investigates the spillover effect of brand crisis on non-affected competing firms' financial values in emerging markets. The main research questions address: (1) whether and how brand crisis spillover influences non-affected competitors' financial market values in emerging markets, and (2) how marketing strategies by rival firms prior to the crisis influence spillover effects on their financial values in emerging markets. The paper conducts an event study to investigate whether and how the stock values of rival firms within the same product category — food brands — are affected by brand crisis released in China from 2001 to 2011. The results show that rival firms report negative abnormal returns at the time of the brand crisis and furthermore, the harm varies depending on three marketing strategies before crisis. Specifically, advertising expenditures of rival firms strengthens, but charity donation (as signal of corporate social responsibility) and the product diversity of rival firms weaken the spillover effect of a brand crisis in a financial market. Accordingly, the findings have provided managerial implications and recommendations regarding future directions.
\end{abstract}

Keywords: customer equity, brand crisis spillover, financial market, advertising, corporate social responsibility, emerging market 


\section{INTRODUCTION}

Customer perception drives customer equity (Blattberg and Deighton 1996; Rust, Lemon, \& Zeithaml 2004). Customer perception is fragile because the perception bases on beliefs and, due to customers' exposure to new information, can be prone to large and sudden incidents outside of management's control (Dawar \& Pillutla 2000). Unexpected incidents such as brand crisis are ubiquitous in the marketplace (Cleeren, van Heerde, \& Dekimpe 2013). A brand crisis may also spill over to non-affected competitors when perceived as guilty by association (Roehm and Tybout 2006). These crises can pose severe damage to customers equity (e.g., Dahlen and Lang 2006; Lei, Dawar, and Gurhan-Canli 2012; Roehm and Tybout 2006; van Heerde, Helsen, and Dekimpe 2007; Zhao, Zhao, and Helsen 2011).

Further, the spillover effect may cause competing firms to suffer indirect costs in the financial market. The increased product market and financial market relatedness may also expose competing firms to unintended risks caused by affected brands when negative incidents occur (Govindaraj, Jaggi \&Lin 2004). A broader understanding of these indirect financial costs resulting from brand crisis spillover is critical as customer equity is affected (Rust, et al 2004). However, the limited empirical work investigating rivals' indirect costs in the stock market has been restricted to developed markets (e.g., U.S.) (Govindaraj et al 2004). Little is understood regarding the indirect costs of competing firms associated with the spillover effect in financial markets of emerging economies.

In recent decades, emerging markets have become increasingly more important in the global economy and few brands ignore emerging markets. However, the characteristics of emerging markets differ distinctly from those of mature markets (Aiello et al 2015; Ghemawat 2001; Hofstede 2001; Marchi, et al 2014). First, in many emerging markets, the public appears to 
have weak brand-consciousness (Sheth 2011) and consequently, people are less aware of brand differentiation (Atsmon, Kuentz, and Seong 2012). Further, in many emerging markets, consumers rely more on social interaction and less on advertising than in Western countries (Money, Gilly, and Graham1988; Pauwels et al 2013). Second, firm self-discipline and consumer protection are key examples of an institutional void typically found in product markets of emerging countries due to the absence of rigorous regulatory systems (Khanna and Palepu 2010; Kim and Schellhase 2015). Finally, unlike mature stock markets in developed countries, individual investors are the majority in China (Chen, Li and Shi 2010). The Chinese markets are under-regulated and deficient in gathering and disseminating information to private or public organizations (Singh 1998). As a result, information asymmetry is accentuated and imperfect signals released from firms highly impact investor decisions. Managers must understand how diverse stakeholders in emerging markets respond to negative brand publicity and firms must understand how to adjust their marketing mix to suit local markets (Sheth 2011).

Furthermore, indirect costs associated with a brand crisis may vary greatly between firms due to marketing actions. To overcome a brand or category crisis, a number of studies have suggested post-crisis countermeasures such as denial, proactive recall policy, and advertising and communication strategies (Ahluwalia, Unnava, and Burnkrant 2001; Chen, Ganesan, and Liu 2009; Cleeren, Dekimpe and Helsen 2008; Cleeren, van Heerde, and Dekimpe 2013; Roehm and Tybout 2006; Dutta and Pullig 2011). However, researchers have been unable to determine which factors prior to a crisis cause variations in indirect costs. Non-affected rivals need proactively develop precautions in the event of a spillover effect from incidental brand crises.

This paper investigates the spillover effect of brand crises in emerging markets. The research questions address: (1) whether and how brand crisis spillover influences non-affected 
competitors' financial market values in emerging markets, and (2) what precautions non-affected competitors can take to protect their market values from the spillover effect.

The study empirically investigates these issues by examining financial market responses to brand crisis in a rapidly growing emerging market - China. The empirical analysis reveals some interesting findings. First, rival firms experienced negative abnormal returns during the brand crisis. Second, the spillover effect of the brand crisis on the financial market is strengthened by rival firms' investment in advertising prior to the crisis but weakened by charity donation and product diversity of rival firms prior to crisis.

This study contributes to marketing literature on customer equity and crisis management in emerging markets and provides some managerial implications. So far as know, this is the first study in marketing on the spillover effect of brand crisis on competitors in the financial markets of emerging markets. In particular, the findings provide a comprehensive reference for managers on how to manage customer equity during periods of market turbulence in emerging markets.

\section{LITERATURE REVIEW}

The spillover over of brand crisis and the impact on customer equity

A brand crisis occurs when (1) a key brand proposition is unsubstantiated or false, (2) a product is cited for failing to meet a mandatory safety standard, (3) a product defect is discovered that could cause substantial harm or an unreasonable risk of serious injury or death, or (4) failure to comply with a voluntary standard adopted by a specific industry (Dawar and Lei 2009; Votolato and Rao 2006). Brand crisis may not only be devastating for the affected brand, but also potentially impact related but non-affected brands through spillover effect. Spillover refers to the phenomenon in which information influences beliefs that are not addressed directly 
in a communication (Ahluwalia, Unnava, and Burnkrant 2001).

Researchers have found that a brand crisis can influence competitors' customer equity. For example, Roehm and Tybout (2006) have reported that a brand scandal negatively affects customers' attitudes and beliefs about the product category and competing brands. Dahlen and Lang (2006) have observed that customers reevaluate category attributes from associations with the brand in crisis; thus, the values attributed to competing brands differ depending on similarity to the affected brand. van Heerde, Helsen, and Dekimpe (2007) have noted an increase in a main competitor's sales after Kraft's crisis in Australia in 1996. Cleeren, van Heerde, and Dekimpe (2013) have recorded changes in brands' market shares and category purchases following brand crises. For financial market reaction, Govindaraj et al (2004) have found that the major competitors in the tire and auto industries experiences a significant gain in the market value of their stocks probably because their products substitute the products affected by recall. This result is inconsistent with those of Jarrell and Peltzman's (1985) that have shown a negative stock price reaction for competitors in the auto industry. However, both the findings are in developed country setting (U.S) and not controlled by potential influence of marketing strategies.

Some studies have examined the influence of marketing variables on stock returns (Luo 2009; Rust et al. 2004; Srinivasan and Hanssens 2009). Several studies have explicated that a firm's advertising directly affects stock returns (Luo 2008), and that advertising goes beyond the consumer to create spillover effects among other stakeholder such as investors (Luo and Bhattacharya 2009). Corporate social responsibility (CSR) has a positive effect on global brand (Torres, et al 2012). As a good sign of CSR, charitable donation is increasingly practiced by companies (Muller and Whiteman 2009; Zhang et al 2010).

Horizontal Product Diversification (HPD) refers to a firm's having a single business (related 
products) or pursuing an unrelated business (products) (Rumelt 1974). HPD can not only create new business growth and revenue but also reduce the risk of bankruptcy (Zhao and Luo 2002). However, all these literatures are studies on mature markets. In immature emerging market, different theory and evidence about consumer and financial markets response may exist in regards to competing firms when a brand crisis occurs because of distinct environment of emerging markets.

\section{HYPOTHESIS DEVELOPMENT}

Spillover effect of brand crises on financial values of competing firms in emerging markets

Customer reaction First, the spillover of a brand crisis might have a negative impact on purchasing decisions of customers in emerging markets that could result in decreased sales and diminished financial performance of competing firms. When a brand receives negative publicity, the brand becomes more salient in customers' minds and may affect perceptions of the product category to a greater extent than previously (Lei, Dawar and Lemmink 2008). The affected brand may prime customers' evaluations of other brands in the same product category that are not fixed but are continually updated when customers encounter new information (Moreau, Markman, and Lehmann 2001). Therefore, with negative publicity priming product category perceptions, customers evaluate similar brands more critically and dissimilar brands more favorably (Dahlen and Lange 2006).

Given the alternative evaluation processes, predicting which evaluation process (i.e., similarity evaluation or dissimilarity evaluation) a customer will pursue is crucial. In comparing a target with a given standard, judges engage in an initial holistic assessment of target-standard similarity; the outcome determines the nature of the hypothesis that is tested in the comparison. 
If the assessment indicates that the target is generally similar to the standard with respect to the judgmental dimension, judges engage in similarity testing. However, if the initial assessment indicates that the target is generally dissimilar from the standard, judges engage in dissimilarity testing. In emerging markets, unbranded products and services comprise as much as $60 \%$ of total consumption (Sheth 2011). Consequently, customers in emerging markets are less aware of brand differentiation compared with customers elsewhere (McKinsey 2012). For these reasons, customers are likely to judge non-affected competing brands to be in the same category of affected brands and do not discriminate from the affected brand by brand differentiation. Further, this holistic screening is sufficient to determine that similarity testing has been conducted. Therefore, emerging market customers are more likely to extend negative beliefs regarding affected brands to non-affected brands within a product category.

Negative publicity is likely the salient feature that lends itself to a holistic assessment during a brand crisis. For example, the 2008 crisis of contaminated Sanlu infant milk powder in China created a prolonged impact on customers' confidence in the Chinese dairy industry. In the wake of this event, many Chinese consumers boycotted domestic brands of powdered milk, stating that they would rather purchase foreign brands and pay much higher prices (Ipsos 2009). In the Sanlu crisis, consumers hardly obtained unbiased information about the quality of non-affected milk powder brands from independent consumer and watchdog organizations. Thus, the salient effect of Sanlu's contamination may have impacted consumers' holistic assessments of other domestic milk powder brands and led them engage in similarity testing, resulting in negative evaluations of other brands. Therefore, to decrease the risk perceptions caused by uncertainty about the quality of an entire category, customers in emerging markets may reduce their purchases of competing brands. As a result, the financial performance of competing firms 
may be impacted significantly (negatively) because of the spillover from a brand crisis.

Investor reactions Although many negative marketing events such as the exposure of a non-affected competing brand to undesirable publicity regarding other brands within a category have no immediate impact on cash flow, these events garner a quick investor response. Investors adjust their valuation of a stock on the basis of a firm's expected cash flow (Luo 2008;

Srivastava, Shervani, and Fahey 1998). Investors may have incentives to include the risk induced from negative brand publicity in their expectations regarding stock values of competing firms and these considerations include the prospects of enhancing/accelerating future cash flow and reducing associated risks (Srivastava, Shervani, and Fahey 1998). Specifically, a brand crisis may generate negative abnormal returns for competing firms if investors perceive the risk as systemic for the entire product category. However, the crisis may not generate negative abnormal returns for competing firms if investors perceive the risk as idiosyncratic to the affected brand. Generally, investors' perceptions depend on whether they primarily think about the differentiation between the affected brand and its competing brands.

Market information may influence investors' leading intuitive theories about the diagnosticity of negative publicity. For example, when information serves as a signal to prime investors to consider brand differences, investors may induce a brand crisis caused only by the affected brand's unique efforts or separate the crisis from a competing brand. As a consequence, negative publicity may not become diagnostic for competing firms. In contrast, when investors lack sufficient information to separate the negative publicity from competing firms, they may infer that the negative characteristics apply to other brands within the category. Common business practices and the same supply chain equate affected and non-affected brands within industries. 
In emerging economies, numerous poorly informed individual investors have difficulty obtaining adequate information to make short-term judgments in brand differentiation. According to a report from China's stock exchanges, in China's financial markets, individuals are the major investors and create the largest amount of transactions. During 2002-2007, individual investors roughly generated $90 \%$ of all trade value, which was approximately eight times the number of institutional trades (Chen et al 2010). In 2011, more than $99 \%$ investors are individuals in Shenzhen stock exchange which is one of the two China's stock exchanges (http://www.p5w.net/stock/ssgsyj/zqgg/201204/t4202054.htm). Thus, the large portion of individual investors could be a characteristic of the Chinese financial market. Individual investor behaviors can significantly impact share price (Da et al 2011). Individual investors hardly gather sufficient information to aid in rational assessments. This information asymmetry is accentuated during brand crisis events (Chen, Ganesan, and Liu 2009), thus imperfect signals released from firms and psychological mechanisms may impact investors' decisions (Chen, Ganesan, and Liu 2009; Strahilevitz, Odean and Odean 2011). Singh, Zammit, Singh and Weisse (2005) reveals that stock markets in developing countries are under-regulated and deficient in gathering and disseminating information to private or public organizations, and listed firms do not have sufficient records to form reputations. Hence, investors are more likely to view the negative performance of an affected brand as the tip of the iceberg, and quality uncertainty surrounding non-affected brands will increase risk perceptions, leading investors to hesitate or discontinue investing in competing firms. In these cases, the brand crisis may spill over to negatively impact the financial performance of competing firms. The hypothesis is the following: $\mathrm{H}_{1}$ : A brand crisis creates negative abnormal stock returns for competing firms in emerging markets. 


\section{Financial value determinants of brand crisis spillover}

\section{Advertising}

Advertising incurred by rival firms before a crisis may strengthens the spillover effect of brand crisis for similar products. In an emerging market, advertising may be not as persuasive as signal theory (Nelson 1978) has argued. First, Money, Gilly, and Graham (1988) have reported that customers in collectivist cultures rely more on social interaction and many emerging markets are in collectivistic cultures (Hofstede 2001; Lee et al. 2015; Muk, Chung and Kim 2014). Consumers are group-oriented, valuing connectedness and conformity and, as a result, they should be less willing to change their attitudes based solely on advertising. Instead, attitude changes mostly derive from interpersonal information exchange or word-of-mouth (Ismail 2015; Kim and Lee 2015; Pauwels et al 2013). For example, when McKinsey surveyed food and beverage consumers in a range of developed and emerging markets, roughly 30 to $40 \%$ of respondents in the U.K. and U.S. said that their purchases were based on recommendations from friends or family members rather than from advertising. The figures were sometimes dramatically higher for consumers in Africa and Asia (i.e., greater than $70 \%$ in China and $90 \%$ in Egypt (McKinsey 2012).

Apart from the function of persuasion, advertising increases public awareness of firms and brands (Servaes and Tamayo 2013). Firms with higher advertising generate greater market awareness and recall among customers (e.g., Dahlen 2001). A firm's advertising strategy may cause positive and negative information to become more salient for stakeholders. Investors and customers can retrieve such characters of category membership of competing firms from memory, so they are more likely associate negative publicity of an affected brand with competing brands and firms. The more prominent the effect created by advertising, the greater 
the association. Accordingly, negative perceptions influence stakeholders' investment decisions, which strengthen the negative impact of the brand crisis on competing firms.

Furthermore, although high advertising expenditures can communicate that a company is financially in good shape (Kirmani and Rao 2000; Kirmani and Wright 1989), as efficient market theory suggests, that positive signals such as higher advertising prior to a crisis are then seized upon by investors who have incorporated the signals into expectations regarding share prices (Ghani and Childs 1999) before the crisis. Although firms with higher ads are a better investment, once when a crisis happens and non-affected rival firms are perceived as guilty by association, this is negative news for investors. As soon as a future change in profitability is anticipated, share price immediately incorporates this new information (Fama 1969). Some investors who are willing to convert the increase in an asset's market value into cash could sell their shares in related firms when the asset has risen and the status begins to reverse. Profit taking by a number of investors normally pushes share prices temporarily downward (Daniel, Hirshleifer, and Teoh 2002), which may cause a trend of negative abnormal returns in the short term. Therefore, advertising expenditures incurred by rival firms before a crisis may strengthen rather than weaken the spillover effect of negative brand publicity for a similar product. Therefore:

$\mathrm{H}_{2}$ : For competing firms in emerging markets, advertising expenditures spent before crises strengthen the negative impact of the brand crisis on a firm's abnormal stock returns.

\section{Charitable donation}

Charitable donations as a CSR signal are likely to weaken the negative impact of spillover in brand crisis. On the one hand, CSR actions before a crisis can indicate slack resources (Surroca, Tribo, and Waddock 2010), and firms with higher donation have more slack resources and are thus better investments. However, the share price before a crisis has already reflected the 
indicator for slack resources. When a crisis happens, investors' profit taking still brings down the stock price if non-affected rival firms are associated with the negative brand publicity. So a slack resource signal derived from donation incurred by rival firms before a crisis may not be enough to weaken the spillover effect of negative brand publicity for a similar product. On the other hand, CSR associations have strong and direct effects on customers' attributions, which translate into blame for the incident that consequently influences evaluations and purchase intentions for the affected brand (Klein and Dawar 2004). The donation of rival firms may play a very important role in weakening brand crisis spilling over regardless of how customers attribute the crisis.

Brand crisis may be attributed to a failure in morality or competence. In the negative information literature, morality is a person's or company's ethics and principles. Negative information in this category could concern behavior (e.g., dishonesty) that conflicts with a customer's established ideal of ethical standards (Ahluwalia, Burnkrant, and Unnava 2000; Sun Kim and Kim 2014; Wojciszke, Brycz, and Borkenau 1993). Competence is the ability of a person or company to deliver on the brand promise made to the customer. Negative information that arises in this category may concern a company's failure to meet quality standards as perceived by customers (e.g., Wojciszke, Brycz and Borkenau 1993).

When sudden events trigger a brand crisis, both investors and customers may use information beyond product associations because existing information is insufficiently diagnostic to make the judgment at hand (Feldman and Lynch 1988). If a brand crisis is attributed to a corporate failure in morality, the halo effect of stakeholders' prior beliefs about a rival firm's position on CSR can cause non-affected competing brands to become isolated from the influence of the crisis. If the brand crisis is attributed to competency failure, donation can reduce the effect by positively influencing customers' brand perceptions. Dawar and Pillutla (2000) suggests that 
(positive) prior evaluations of brands create a hypothesis-confirming context in which customers interpret crisis information and lead to a diminished negative impact on brand evaluations. Importantly, such evaluations can be derived from CSR (Holt, Quelch, and Taylor 2004; Kim 2015). Sociopolitical and faith-based institutions such as religion, government, professional organizations, and nongovernmental organizations (NGOs) govern emerging markets. Further, local communities have a more a powerful influence in emerging markets than anywhere else (Sheth 2011). Donation aimed at the local community can reinforce positive effects on brand evaluations and reduce harm from brand crisis.

Overall, CSR influences stakeholders' investment decisions, that is, during a brand crisis, charitable donations as a CSR signal weakens the negative impact of spillover.

$\mathrm{H}_{3}$ : For competing firms in emerging markets, charitable donations before crises weaken the negative impact of a brand crisis on abnormal stock returns.

\section{Horizontal Product Diversification (HPD)}

HPD strategy tends to increase a firm's dependence on certain market segments.(Ansoff 1957). A potential advantage of HPD is a reduced bankruptcy risk because of imperfectly correlated earnings streams across different businesses. This coinsurance effect can give firms greater debt capacities (Berger and Ofek 1995; Schmid and Walter 2009).

Even though negative spillover affects rivals, HPD is a way to manage risk. By removing all of the focus from one area and spreading it among many different areas, firms have less reliance on any one area. Consequently, competing firms that utilize HPD can minimize the negative effect in a limited product category and avoid universal market damage and financial bankruptcy. Overall, HPD may reduce both the possibility of spillover and its negative effects. The resulting hypothesis follows. 
$\mathrm{H}_{4}$ : For competing firms, HPD weakens the negative impact of a brand crisis on abnormal stock returns.

\section{METHOD}

Data

The study empirically examines the spillover of brand crisis on financial markets in emerging economies by evaluating Chinese food brand crises, reported on the website http://zccw.info during the period 2001 to 2011. This website collects the events of food product crises reported by media. As the definition of brand crisis (Dawar and Lei 2009; Votolato and Rao 2006), mainstream media (e.g., newspapers) or government reports identify the 98 selected cases. Using a method similar to Chen, Ganesan, and Liu (2009), Tipton, Bharadwaj, and Robertson (2009), and Jarrell and Peltzman (1985), the study combines a sample of 312 publicly traded food firms with the same product as affected brands in each case, excluding firms owning the affected brands. The study collects daily returns and corresponding market returns from RESSET Financial Research Database (e.g., Guo and Fung 2011; Huang and Li 2012), a commonly used financial database for the Chinese stock market.

The study chose the food industry for sampling. First, as customers are exposed to food products every day, defects or social/environmental problems created by firms that market these products would impact customers' health directly and therefore customers and investors would be deeply involved in a brand crisis. Second, marketing actions implemented by food manufacturers are likely to draw attention from customers and media.

\section{Event Study Methodology}

The study adopts an event study methodology to examine the spillover impact of brand 
crises in emerging markets. Event study has been a widely used method for analyzing short-term stock market returns in finance and accounting (Kothari and Warner 2007). Recently, the event study has been used for examining negative brand behaviors on stock market returns (Chen, Ganesan, and Liu 2009; Tipton, Bharadwaj, and Robertson 2009).

Given the market efficiency theory (Fama 1969), perfect information, and the rationality of investors, the effect of a relevant event should be reflected immediately in stock prices (Srinivasan and Hanssens 2009). Thus, any abnormal change in the price of a stock due to the arrival of new information reflects the present value of all expected current and future profits from the new information (Sood and Tellis 2009).

The study estimates the abnormal return to the event (i.e., negative publicity of food brand) using the ex-post return of the stock during the course of the event window minus the normal expected return. Specifically, the study estimates the normal expected return using the market model (MacKinlay 1997) as:

$R_{i t}=\alpha_{i}+\beta_{i} R_{m t}+\varepsilon_{i t}$,

where $R_{i t}$ and $R_{m t}$ are the daily stock returns $i(i=$ publicly traded food firms) and a standard market portfolio at day $t$. Following the literature, the study uses $t=\{-270, \ldots,-21\}$ as the estimation window for predicting the normal returns of stock $i$; further, the study uses market portfolio in the estimation and applies the estimated $\hat{\alpha}_{i}$ and $\hat{\beta}_{i}$ in the event window to calculate the abnormal returns and cumulative abnormal returns of stock $i$ in the event window as: $A R_{i t}=R_{i t^{-}} \hat{\alpha}_{i}-\hat{\beta}_{i} R_{m t}$ and $C A R_{i t}=\sum_{t} A R_{i t}$

where $A R_{i t}$ and $C A R_{i t}$ denote abnormal returns and cumulative abnormal returns at the event window $t$. To capture possible information leakage prior to the official announcement and possible delayed responses after the official announcement, the study calculates the cumulative 
abnormal returns at different event windows (e.g., $[-1,1]$ and $[-2,2])$.

\section{Regression Analysis Model}

The study develops a regression model to further examine the impact of negative food brand publicity on accruing abnormal returns for the food firm $i$ by incorporating advertising, donations, and HPD, specifically, test the effects proposed in Hypotheses $\mathrm{H}_{2}-\mathrm{H}_{4}$ :

$C A R_{i}=\alpha+\beta_{1} A D_{i}+\beta_{2} D N T_{i}+\beta_{3} H P D_{i}+\beta_{4} D E T_{i}+\beta_{5} O W N E R_{i}+\beta_{6} S I Z E_{i}+\beta_{7} M T B_{i}+\xi_{i}$,

where $A D, D N T$, and $H P D$ denote three strategies: advertising expenditures, charitable donations, and HPD, respectively. The study collects relevant data for each strategy from firms' annual financial reports; HPD is measured by the number of unrelated product categories a firm produces (Delios, Zhou and Xu 2008; Rumelt 1974). In line with the literature (e.g., Zhang et al. 2010, Luo and Bhattacharya 2009; Srinivasan et al. 2009), the study measures DNT as amount of donations divided by sales and $\mathrm{AD}$ as advertising expenditures divided by assets in corresponding year before the crisis occurred.

the regression incorporates four control variables, OWNER, DET, SIZE, and MTB, to capture the impact of ownership structure (Tanriverdi and Uysal 2011), debt rate (debt amount divided by total asset)(Wiles, Morgan, and Rego 2012), firm size (Chen, Ganesan, and Liu 2009) and intangible assets (Godfrey, Merrill and Hansen 2009) on abnormal stock returns, respectively. The study derives data from firms' annual financial reports. The study use the share ratio of the top ten shareholders to measure ownership structure (Claessens, Djankov, and Lang. 2000; Zhang et al. 2010). Firm size is measured as the natural logarithm of sales for the fiscal year before the event (Chen, Ganesan, and Liu 2009). The natural logarithm of the market to book strongly relate with Tobin's q, measuring intangible assets (Villalonga 2004). Table 1 summarizes the variables and descriptive statistics incorporated in the regression model. 
[Insert Table 1 here]

RESULTS

To analyze stock market responses to brand crisis, the study first examines the cumulative abnormal returns accruing to all rival firms at various event windows (e.g., $[-1,0]$ and $[-1,1])$. To isolate the impact of brand crisis, the study eliminates those firms that became involved in confounding events (including earnings, dividends, etc.) on the initial date of brand crisis. Table 2 presents the cumulative abnormal returns at different event windows along with results of the t-test statistics.

[Insert Table 2 here]

As shown in Table 2, the cumulative abnormal returns for rival firms are significantly negative at certain event windows (e.g., $0,[-1,0],[-1,1],[-1,2]$, and $[-2,2])$. For example, on the initial date of negative publicity, the average abnormal returns range from $-1.2 \%$ to $-1.7 \%$.

On the wider windows, the average abnormal returns are significantly negative (e.g., the average cumulative abnormal return is $-4.9 \%$ at the event window of $[-2,2])$. These results support $\mathrm{H}_{1}$, suggesting that the negative publicity of an affected brand creates significantly negative abnormal returns for non-affected rival firms when a crisis occurs.

With the cumulative abnormal returns reported in Table 2, the study estimate the regression model (3) to examine the effects proposed in Hypotheses $\mathrm{H}_{2}-\mathrm{H}_{4}$. Table 3 presents Regression model estimates by events.

[Insert Table 3 here]

As shown in Table 3, the estimation provides a comparable model fit (adjusted $R^{2}=0.26$ in the table) with existing works using event study (e.g., adjusted $R^{2}=0.16$ in Chen, Ganesan, and Liu [2009]; $R^{2}=0.17$ in Tipton, Bharadwaj, and Robertson [2009]). Regarding the effect of 
advertising proposed in $\mathrm{H}_{2}$, the coefficient of advertising is associated significantly and negatively with $\operatorname{CAR}\left(\beta_{l}=-0.45, p<0.05\right)$, suggesting that advertising strengthens the negative impact of the brand crisis on stock returns of competing firms, thus supporting $\mathrm{H}_{2}$. The coefficient of donations is associated significantly and positively with $\operatorname{CAR}\left(\beta_{2}=0.34, p<0.05\right)$, suggest that charitable donations weaken the negative impact of a brand crisis, thus supporting $\mathrm{H}_{3}$. Further, the coefficient of HPD is associated significantly and positively with $\mathrm{CAR}\left(\beta_{3}=\right.$ 0.03, $p<0.05)$. The results suggest that HPD also weakens the negative impact of a brand crisis, thus supporting $\mathrm{H}_{4}$.

\section{IMPLICATIONS}

\section{Theoretical implications}

First, this study extends existing research on the spillover effect of a brand crisis in stock market from developed markets (Govindaraj et al2004;Jarrell and Peltzman 1985) to emerging markets. Specifically, by providing empirical evidence concerning market responses to brand crisis, this study have shown that brand crisis in emerging markets destroys the value of competing firms because of unbranded competition and accentuated information asymmetry.

Second, this study also contributes to customer equity literature by advancing the understanding of the interactions between brand crisis and marketing strategies prior to crisis. Although prior studies (e.g., Roehm and Tybout 2006) have shown the interplay of advertising for preventing the spillover of brand crisis (i.e., by reducing associations between affected brands and non-affected competing brands through differentiation among products), this study shows the opposite interplay of advertising in financial market of emerging market. Advertising before crisis increases rather than decreases stakeholders' associations between affected and 
non-affected brands.

\section{Empirical implications}

The findings provide several managerial implications for firms. First, the findings warn to both domestic and global brands as follows: (1) in emerging markets, non-affected competing brands hardly escape scathe from brand crisis, and (2) managers must not only enhance internal quality control to avoid a scandal but they must also be alert to negative spillover from other brands within the same product category. Further, this finding suggests that investors in emerging markets should not only be aware of the loss for affected firms but also the potential risk for competing firms when making investment decisions.

Second, the findings provide guidance regarding prevention strategies for brand crises spillovers. Although CSR is a new concept for emerging market consumers and investors, it is valuable for firms to engage in related activities. Such actions build trust and enhance the corporate reputation. For global brands to be successful in emerging markets, the findings suggest that companies should demonstrate a commitment to CSR in emerging markets just as they have done in developed markets. This commitment is not only necessary for companies but also provides financial and branding rewards.

Third, the findings imply that not all marketing instruments uniformly help firms recover from the spillover of a brand crisis in an emerging market. In contrast, the results indicate that non-affected firms with larger advertising expenditures prior to a crisis suffer greater financial loss from brand crisis. Thus, in emerging markets, advertising is a double-edged sword that causes innocent competing brands to be negatively associated with scandalized brands.

Finally, HPD can not only create new business growth and revenue but also reduce the risk of bankruptcy. HPD is an efficient strategy to limit a brand crisis within categories and minimize 
potential damage to the financial market value.

\section{CONCLUSION}

Whereas previous research has explored the spillover of a brand crisis from one brand to members of a brand family, alliance, or other brands within consumer market, the study addresses spillover from an affected brand to competing brands in the financial market.

The study makes some implications for customer equity management to cope with brand crisis in emerging market. First, as non-affected brand, integrating financial market value into customer equity management values because investors may overreact due to serious information asymmetry in the crisis period. Second, doing CSR can be an effective alternative for creating awareness and building up a customer equity. Finally, when allocating limited resources to marketing strategies, firms do not make marketing decisions independently. The concept (i.e. think global, act local) suggests that the marketing mix (e. g. advertising) for a global brand should be adjusted to suit local markets.

\section{Future Research}

This study focuses on stock market responses in one of the fastest growing emerging markets - China. Future works are to examine other emerging markets such as Brazil or India, or compare the financial outcome of similar events in developed and developing economies.

Furthermore, this study focuses on the short-term financial potential in emerging markets using an event study methodology. Future research regarding the dynamic impact on customer equity in emerging markets would provide valuable insights about global brand management if enough samples could be collected in each period. 


\section{References}

Ahluwalia, R., Burnkrant, R. E., \& Unnava, H. R. (2000). Consumer Response to Negative Publicity: The Moderating Role of Commitment. Journal of Marketing Research, 37, $203-214$.

Ahluwalia, R., Unnava, H.R., \& Burnkrant, R.E. (2001). The Moderating Role of Commitment on the Spillover Effect of Marketing Communications. Journal of Marketing Research, 38 (6), $458-471$.

Aiello, G., Raffaele, Do., Laura, G., Halliburton, C., Wagner, B., Wilson, J., Godey, B., Pederzoli, D., \& Shokola, I. (2015). An international comparison of "Made in Italy" in the fashion, furniture and food sectors: An observational research study in France, Russia and The United Kingdom. Journal of Global Fashion Marketing, 6(2), 136-149.

Ansoff, I. (1957). Strategies for Diversification. Harvard Business Review, 35(5), 113-124.

Berger, P. G. \& Ofek, E. (1995). Diversification's Effect on Firm Value. Journal of Financial Economics, 37(1), 3-21.

Blattberg, R.C. \& Deighton,J. (1996).Manage Market-ing by the Customer Equity Test. Harvard Business Review, 74(4), 136-144.

Chen, W., Li, Z., \&Shi, Y. (2010). Do All Individual Investors Lose by Trading. Proceedings of the 2010 Annual Meeting of the Academy of Behavioral Finance and Economics, September 15-17, Chicago, Illinois

Chen, Y., Ganesan, S., \& Liu, Y. (2009). Does a Firm’s Product-Recall Strategy Affect Its Financial Value? An Examination of Strategic Alternatives during Product-Harm Crises. Journal of Marketing, 73 (6), 214-226. 
Cheung, R., Lam, Y.C. \& Lau M. (2015). Drivers of green product adoption: the role of green perceived value, green trust and perceived quality. Journal of Global Scholars of Marketing Science, 25(3), 232-245.

Claessens, S., Djankov, S., \& Lang.H.P. (2000). The Separation of Ownership and Control in East Asian Corporations. Journal of Financial Economics, 58(2), 81-112.

Cleeren, K., van Heerde, H. J., \& Dekimpe, M. G. (2013). Rising from the Ashes: How Brands and Categories Can Overcome Product-Harm Crises. Journal of Marketing, 77(2), 58-77.

Cleeren, K., Dekimpe, M. G., \&Helsen K. (2008). Weathering product-harm crises. Journal of the Academy of Marketing Science, 36 (2), 262-270,

Da, Z., Engelberg, J., \& Gao, P. (2011). In Search of Attention, Journal of Finance 66(5): $1461-1499$

Daniel, K., Hirshleifer, D., \& Teoh, S.H. (2002). Investor Psychology in Capital Markets:

Evidence and Policy Implications. Journal of Monetary Economics, 49(2), 139-209.

Dahlen, M. (2001). Banner Ads through a New Lens. J Advert Res, 41, 23-30.

Dahlen, M. \& Lange, F. (2006). A Disaster is Contagious: How a Brand in Crisis Affects Other Brands. Journal of Advertising Research, 46(4), 388-397.

Dawar, N. \& Lei, J. (2009). Brand Crises: The Roles of Brand Familiarity and Crisis Relevance in Determining the Impact on Brand Evaluations. Journal of Business Research, 62, 509-516.

Dawar, N. \& Pillutla, M. M. (2000).Impact of Product-Harm Crises on Brand Equity: The Moderating Role of Consumer Expectations. Journal of Marketing Research, 37(3), 215-226.

Delios, A., Zhou, N., \&Xu, W. (2008). Ownership structure and the diversification and the 
performance of publicly-listed companies in China. Business Horizons, 51(6), 473-483.

Dutta, S. \& Pullig, C. (2011). Effectiveness of Corporate Responses to Brand Crises: The Role of Crisis Type and Response Strategies. Journal of Business Research, 64(12), 1281-1287.

Fama, E.F., (1969). Efficient Capital Markets: A Review of Theory and Empirical Work. Journal of Finance, 25(3), 383-417.

Feldman, J. \& Lynch, J. (1988). Self-generated Validity and Other Effects of Measurement on Belief, Attitude, Intention, and Behavior. Journal of Applied Psychology, 73(3), 421-435.

Ghani, W.I. \& Childs, N.M. (1999). Wealth Effects of the Passage of the Nutrition Labeling and Education Act of 1990 for Large U.S. Multinational Food Corporations. Journal of Public Policy \& Marketing, 18(2), 147-158.

Ghemawat, P. (2001). Distance Still Matters: The Hard Reality of Global Expansion. Harvard Business Review, 79 (9), 3-11.

Godfrey, C. P. , Merrill, B. C., \& Hansen, J, (2009). The relationship between corporate social responsibility and shareholder value: an empirical test of the risk management hypothesis. Strategic Management Journal, 30(4), 425 - 445

Govindaraj, S., Jaggi, B. \& Lin, B. (2004). Market Overreaction to Product Recall Revisited - the Case of Firestone Tires and the Ford Explorer. Review of Quantitative Finance and Accounting, 23 (1), 31-54.

Guo, H. \& Hunggay, F. (2011). The Growth Enterprise Board IPOs: Characteristics, Volatility and the Initial-day Performance. China \& World Economy, 19, 106-121.

Hofstede, G. (2001). Culture's Consequences, 2nd Ed. Thousand Oaks, CA: Sage Publications. Holt, D. B., Quelch, J. A. \& Taylor, E. L. (2004). How Global Brands Compete. Harvard 
Business Review, 82(9), 68-75.

Huang, F. and Li, C. (2012). Comparisons of PE and PB between SDB and Vanke A. International Journal of Business and Management, 5(5), 124-129.

Ipsos. (accessed September 1, 2012), [available at http://www.ipsos.com.cn/sites/default/files/EN\%20200901_1.pdf 2009]

Ismail, A. R. (2015). Leveraging the potential of word of mouth: The role of love, excitement and image of fashion brands. Journal of Global Fashion Marketing, 6(2), 87-102.

Jarrell, G., \& Peltzman, S. (1985). The Impact of Product Recalls on the Wealth of Sellers. Journal of Political Economy 93 (3), 512-536.

Khanna, T., \& Palepu, K. G. (2010), Winning in Emerging Markets: Spotting and Responding to Institutional Voids. Boston: Harvard Business Press.

Kim J. (2015). Sustainability in social brand communities: influences on customer equity. Journal of Global Scholars of Marketing Science, 25(3), 246-258.

Kim, J. \& Schellhase, R. (2015). Sustainable Marketing in Asia and the World. Journal of Global Scholars of Marketing Science, 25(3), 195-197.

Kim H.Y. \& Lee, E. (2015). Effect of psychological closeness on consumer attitudes toward fashion blogs: the moderating effect of fashion leadership and interpersonal LOV. Journal of Global Fashion Marketing, 6(2), 103-121.

Kirmani, A. \& Rao, R. A. (2000). No Pain, No Gain: A Critical Review of the Literature of Signaling Unobservable Product Quality. Journal of Marketing, 64 (2), 66-79

Kirmani, A. \& Wright, P. (1989).Money talks: perceived advertising expense and expected product quality. Journal of Consumer Research, 16, 344-352. 
Klein, J. \& Dawar N. (2004). Corporate Social Responsibility and Consumers'Attributions and Brand Evaluations in a Product-harm Crisis. International Journal of Research in Marketing, $21,203-217$.

Kothari, S. P. and Warner, J. B. (2007). Econometrics of Event Studies. B. E. Eckbo, ed. Handbook of Corporate Finance, Vol. 1. North Holland, Amsterdam, 3-36.

Lee, M. E., Li, J. J , \& Park, H. H. (2015). The differential effectiveness of scarcity message type on impulse buying: A cross-cultural study. Journal of Global Scholars of Marketing Science, $25(2), 142-152$.

Lei, J., Dawar, N. \& Gurhan-Canli, Z. (2012). Base-Rate Information in Consumer Attributions of Product-Harm Crises. Journal of Marketing Research, 49(3), 336-348.

Lei, J., Dawar, N. \& Lemmink, J. (2008). Negative Spillover in Brand Portfolios: Exploring the Antecedents of Asymmetric Effects. Journal of Marketing, 72 (3), 111-123.

Luo, X. (2008). When Marketing Strategy First Meets Wall Street: Marketing Spendings and Firms’ Initial Public Offerings. Journal of Marketing, 72 (5), 98-109.

Luo, X. (2009). Quantifying the Long-Term Impact of Negative Word of Mouth on Cash Flows and Stock Prices. Marketing Science, 28(1), 148-165.

Luo, X. \& Bhattacharya, C.B. (2006). Corporate Social Responsibility, Customer Satisfaction, and Market Value. Journal of Marketing, 70 (5), 1-18.

Luo, X. and Bhattacharya, C. B. (2009).The Debate over Doing Good: Corporate Social Performance, Strategic Marketing Levers, and Firm-Idiosyncratic Risk. Journal of Marketing, $73(6), 198-213$.

MacKinlay, C.A. (1997).Event Studies in Economics and Finance. Journal of Economic 
Literature, 35(1), 13-39.

Marchi, G., Martinelli, E. \& Balboni, B, (2014). The country of origin effect on retailer buying behavior: a cross-country analysis on Italian footwear. Journal of Global Fashion Marketing, $5(2), 122-134$.

McKinsey, Building brands in emerging markets. McKinsey quarterly 20129.

Money, B. R., Gilly, M. C. \& Graham, J. L. (1988). Explorations of National Culture and Word-of- Mouth Referral Behavior in the Purchase of Industrial Services in the United States and Japan. Journal of Marketing, 62, 76-87.

Moreau, C., Page, A., Markman, A. B., \& Lehmann, D. R. (2001). What Is It? Categorization Flexibility and Consumers' Responses to Really New Products. Journal of Consumer Research, 27(4), 489-498.

Muk, A., Chung, C. \& Kim, J. (2014). Korean consumer perspectives on social media advertising and intention to join brand pages. Journal of Global Scholars of Marketing Science, 24(4), 384-394.

Muller, A. \& Whiteman, G. (2009). Exploring the Geography of Corporate Philanthropic Disaster Response: A Study of Fortune Global 500 Firms. Journal of Business Ethics, 84(4), 589-603.

Nelson, P. (1970). Information and Consumer Behavior. Journal of Political Economy, 78(2), 311-329.

Pauwels, K., Erguncu, S. \& Yildirim, G. (2013). Winning Hearts, Minds and Sales: How Marketing Communication Enters the Purchase Process in Emerging and Mature Markets. International Journal of Research in Marketing, 30(1), 57-68.

Roehm, M. L. \& Tybout. A. M. (2006). When Will a Brand Scandal Spill Over, and How Should 
Competitors Respond? Journal of Marketing Research, 43(3), 366-373.

Rumelt, R. P. (1974). Strategy, Structure and E Economic Performance. Cambridge: MA, Harvard University Press.

Rust, R. T., Lemon, K. N., and Zeithaml, V. A. (2004). Return on Marketing: Using Customer Equity to Focus Marketing Strategy. Journal of Marketing, 68 (1), 109-27.

Schmid, M. M. \& Walter, I. (2009). Do Financial Conglomerates Create or Destroy Economic Value? Journal of Financial Intermediation, 18(2), 193-216.

Servaes, H. \& Tamayo, A. (2013). The Impact of Corporate Social Responsibility on Firm Value: The Role of Customer Awareness. Management Science, 59 (5), 1045-1061.

Sheth, J. N. (2011). Impact of Emerging Markets on Marketing: Rethinking Existing Perspectives and Practices. Journal of Marketing, 75 (4), 166-182.

Singh, A. (1998). Liberalisation, the Stock Market and the Market for Corporate Control: A Bridge Too Far for the Indian Economy? India's Economic Reforms and Development: Essays for Manmohan Singh, Ahluwalia, IJ and Little IMD (eds.), Oxford, 169-196.

Singh, A, J. Glen, A., Zammit, R. De-Hoyos, Singh, A. \& Weisse, B. (2005). Shareholder Value Maximisation, Stock Market and New Technology: Should the US Corporate Model Be the Universal Standard? International Review of Applied Economics, 19(4), 419-437.

Sood, A. and Tellis, G. J. (2009).Do Innovations Really Payoff? Total Stock Market Returns to Innovation. Marketing Science, 28(3), 442-456.

Srinivasan, S. \& Hanssens, D. M. (2009). Marketing and Firm Value: Metrics, Methods, Findings, and Future Directions. Journal of Marketing Research, 46 (3), 29

Srivastava, R., Shervani, T. A. \& Fahey, L. (1998). Market-Based Assets and Shareholder Value: 
A Framework for Analysis. Journal of Marketing, 62 (1), 1-18.

Strahilevitz, M. A., Odean, T., and Odean, M.B, (2011). Once Burned Twice Shy: How Naïve Learning, Counterfactuals, and Regret Affect the Repurchase of Stocks Previously Sold. Journal of Marketing Research, 48 (1), S102-S120.

Sun, Y, Kim, K. H. \& Kim, J. (2014). Examining relationships among sustainable orientation, perceived sustainable marketing performance, and customer equity in fast fashion industry. Journal of Global Fashion Marketing, 5(1), 74-86

Surroca, J., Tribo, A.J., \& Waddock, S. (2010). Corporate Responsibility and Financial Performance: The Role of Intangible Resources. Strategic Management Journal, 31 (5), 463-490.

Tanriverdi, H. \& Uysal, V.B. (2011). Cross-Business Information Technology Integration and Acquirer Value Creation in Corporate Mergers and Acquisitions. Information Systems Research, 22(4), 703-720.

Tipton, M. M., Bharadwaj, S. G. \& Robertson, D. C. (2009). Regulatory Exposure of Deceptive Marketing and Its Impact on Firm Value. Journal of Marketing, 73 (6), 227-243.

Torres, A. T., Bijmolt, H. A., Tribó, J. A., \& Verhoef, P. (2012). Generating Global Brand Equity through Corporate Social Responsibility to Key Stakeholders. International Journal of Research in Marketing, 29(1), 13-24.

van Heerde, H., Helsen, K. \& Dekimpe, M. G. (2007).The Impact of a Product-Harm Crisis on Marketing Effectiveness. Marketing Science, 26(2), 230-245.

Villalonga, B. 2004. Intangible resources, Tobin's q, and sustainability of performance differences. Journal of Economic Behavior \& Organization 54: 205-230.

Wiles, M.A., Morgan, N.A., and Rego, L.L. (2012). The Effect of Brand Acquisition and 
Disposal on Stock Returns. Journal of Marketing, 76(1), 38-58.

Wojciszke, B., Brycz, H. \& Borkenau, P. (1993). Effects of Information Content and Evaluative Extremity on Positivity and Negativity Biases. Journal of Personality and Social Psychology, 64, 327-335.

Votolato, N. L. and Rao, H. (2006). Spillover of Negative Information on Brand Alliances Unnava. Journal of Consumer Psychology, 16(2), 196-202.

Zhang, R., Zhu, J., Yue, H. \& Zhu, C. (2010). Corporate Philanthropic Giving, Advertising Intensity, and Industry Competition Level. Journal of Business Ethics, 94(1), 39-52.

Zhao, Y., Zhao, Y. \& Helsen, K. (2011). Consumer Learning in a Turbulent Market Environment: Modeling Consumer Choice Dynamics after a Product-harm Crisis. Journal of Marketing Research, 48 (2), 255-267.

Zhao, H. a\& Luo, Y. (2002). Product Diversification, Ownership Structure, and Subsidiary Performance in China's Dynamic Market. Management International Review, 42 (1), 27-48. 
Table 1 Descriptive Statistics for Variables

\begin{tabular}{lllll}
\hline Variables & Mean & Std. & Min. & Max. \\
\hline Advertising Spending $(A D)$ & 0.1 & 0.11 & 0.01 & 0.56 \\
\hline Donation $(D N T)$ & 0.3 & 0.14 & 0.11 & 0.75 \\
\hline HPD & 20.1 & 1.24 & 16.35 & 23.32 \\
\hline Firm size $($ SIZE) & 9.3 & 1.08 & 7.91 & 10.47 \\
\hline Market to book $(M T B)$ & 1.3 & 0.84 & 0.35 & 2.25 \\
\hline Debt $(D E T)$ & 0.2 & 0.16 & 0.0003 & 0.70 \\
\hline Ownership $(O W N E R)$ & 0.3 & 0.20 & 0.02 & 0.84 \\
\hline
\end{tabular}

Table 2 Cumulative Abnormal Returns of Competing Firms during a Brand Crisis

\begin{tabular}{lllll}
\hline Event Window & MRET_TMV & MRET_MC & CSI 800 & CSI 300 \\
\hline 0 & $-0.013 * * *$ & $-0.012 * * *$ & $-0.017 * * *$ & $-0.015 * * *$ \\
{$[-1,0]$} & $-0.017 * * *$ & $-0.014 * * *$ & $-0.029 * * *$ & $-0.026 * * *$ \\
{$[-1,1]$} & $-0.039 * * *$ & $-0.037 * * *$ & $-0.058 * * *$ & $-0.051 * * *$ \\
{$[-1,2]$} & $-0.037 * * *$ & $-0.037 * * *$ & $-0.067 * * *$ & $-0.054 * * *$ \\
{$[-2,1]$} & $-0.038 * * *$ & $-0.039 * * *$ & $-0.061 * * *$ & $-0.050 * * *$ \\
{$[-2,2]$} & $-0.040 * * *$ & $-0.039 * * *$ & $-0.065 * * *$ & $-0.053 * * *$ \\
\hline Note ${ }^{* * *}: p<001$ & & & & \\
\hline
\end{tabular}

MRET_TMV, MRET_MC,CSI 800 and CSI 300 are four different stock market indexes: 
Table 3 Regression Analysis of Cumulative Abnormal Returns

\begin{tabular}{|l|l|l|l|}
\hline & Unstandardized coefficients & Std.error & $t$ \\
\hline$A D$ & -0.45 & 0.19 & $-2.38^{*}$ \\
\hline DNT & 0.34 & 0.14 & $2.33^{*}$ \\
\hline HPD & 0.03 & 0.00 & $3.14 *$ \\
\hline DET & -0.06 & 0.09 & -0.65 \\
\hline OWNER & 0.02 & 0.05 & 0.31 \\
\hline SIZE & 0.01 & 0.00 & 0.02 \\
\hline MTB & -0.02 & 0.00 & -0.03 \\
\hline constant & -0.21 & & -0.49 \\
\hline F-value & $2.42^{* *}$ & & \\
\hline Adj. $\mathrm{R}^{2}$ & 0.26 & & \\
\hline df & 248 & & \\
\hline
\end{tabular}

*: $p<0.05$ 